\title{
A Study on Emotional Intelligence In Relation To Academic Efficiency, Gender and Birth Order among Technical Graduates: In Indian Context
}

\author{
B.Vasavi ${ }^{*}$, J. Katyayani ${ }^{2}$, B. Sudhir ${ }^{3}$
}

\section{ABSTRACT}

The primary aim of this investigation is to assess the relationship between emotional intelligence and academic efficiency among technical graduates. The secondary aim is to investigate the role of demographic variables such as gender and birth order in emotional intelligence. A standardized questionnaire is used to conduct the study and data was collected from 176 final year engineering graduates using random sampling method. Data is analyzed using Pearson's correlation coefficient method to find the relation between independent variable Emotional Intelligence (EI) and dependent variable Academic Efficiency (AE).The study revealed that there is positive correlation between Emotional Intelligence (EI) and Academic Efficiency (AE). Descriptive statistics of the study revealed that female students have higher level of EI than male students and first born students have higher EI than later born students.

Keywords: Emotional intelligence (EI), Academic Efficiency (AE), Birth order, Gender.

For decades Emotional Intelligence (EI) has been accepted as the best gauge or predictor for an individual's success in life. It has received a substantial amount of attention in the Organizational Behavior and Human Resources Management. Recent research highlights the importance of EI as a predictor in important domains such as academic performance, job performance, negotiation, leadership, trust, and stress (Ashkanasy, N.M C.S Daus, (2002), Humphrey, R.H (2002), Humphrey R.H.(2006), Jordan, P.J Ashkanasy, N.M Hartel, C.E.J (2002)). Emotional intelligence is a collection of capabilities such as self-awareness, empathy, self-regulation, selfmotivation and social skills that can impact behavioral performance of an individual (Goleman, 1995). Emotional intelligence refers to individual differences in the ability to monitor one's own

\footnotetext{
${ }^{1}$ Assistant professor, NBKR Institute of Science \& Technology, Vidyanagar, SPSR Nellore District 524413, Andhra Pradesh, India

${ }^{2}$ Professor, Business management, Sri Padmavathi Mahila Visvavidyalayam, Tirupathi, Chittor District, India

${ }^{3}$ Professor, Business management, Sri Venkateswara University, Tirupathi, Chittor, India

*Responding Author
}

Received: January 20, 2017; Revision Received: February 4, 2017; Accepted: February 7, 2017

(C) 2017 Vasavi B; licensee IJIP. This is an Open Access Research distributed under the terms of the Creative Commons Attribution License (www.creativecommons.org/licenses/by/2.0), which permits unrestricted use, distribution, and reproduction in any Medium, provided the original work is properly cited. 


\section{A Study on Emotional Intelligence In Relation To Academic Efficiency, Gender and Birth Order among Technical Graduates: In Indian Context}

and others' feelings and emotions, to discriminate them and to use this information to guide one's thinking and actions. These differences have been shown to have a significant effect on life outcomes such as mental health, social relationships and work performance. Salovey \& Mayer (1989) were first to propose a formal definition of EI as "a sub set of social intelligence that involves the ability to monitor one's own and other's feelings and emotions ,to discriminate them and to use this information to guide one's thinking and actions. Mayer and Salovey (1997) noted that emotional intelligence has four abilities: (1) The ability to get your own emotions and others (Perception of emotions). (2) The ability of Emotional perception to be used in other mental processes (Facilitating emotional thoughts). (3) Understanding and evaluating emotional information, and how to combine the excitements and spread through interaction and communication (Emotional understanding). (4) Ability to regulate their emotions and acceptance of self and others (managing emotions).

Academic achievement occupies a very important place in education as well as in the learning process. In our society academic achievement is considered as a key criterion to judge one's total potentialities and capacities. Academic achievement has always been considered to be a very important factor in the educational life of an individual, because good academic record over years predicts future success of a person. In present days, achievement and evaluations are not only interpreted in terms of IQ but also other factors like social intelligence, emotional intelligence, spiritual and creativity and in terms of so many factors. Emotional intelligence and academic achievement have become a prime interest for the teachers, educationists, psychologists and parents to predict student's academic success.

\section{LITERATURE REVIEW}

Emotional intelligence is a dynamic construct influenced by diverse biological, psychological, and social factors. Numerous studies were conducted to find out the impact of demographic variables such as gender, birth order, geographic origin and socio economic status on emotional intelligence of individuals.

\section{Emotional Intelligence and Gender}

There is a common belief held in society that females experience and express their emotions more intensely than their male counterparts (Grossman \& Wood, 1993). A study on gender differences in emotional experience found that, women described themselves as more affectively intense, more open and sensitive to their feelings, more anxious, more sad, and more happy, than men (Feldman Barrett, Robin, Pietromonaco \& Eyssell, 1998).Another study explored that girls developed verbal skills earlier than boys' that means they were more skilled in articulating their feelings and have greater expertise of using words.(Herbert and Stipek (2005) According to Goleman (1996) there is little gender differences in adulthood between the typical characteristics of males and females who score high in measures of EI. Feldman Barrett, Lane, Sechrest and 


\section{A Study on Emotional Intelligence In Relation To Academic Efficiency, Gender and Birth Order among Technical Graduates: In Indian Context}

Schwartz (2000) looked at sex differences in emotional awareness and found that females have more detailed and complex representation of emotions than men. It was confirmed and identified that men are less emotionally expressive than women because they can understand and recognize emotions better. (Carysi (2001).

\section{Emotional Intelligence and Academic Efficiency}

Research on emotional intelligence (EI) suggests that it is associated with more pro-social behavior and better academic performance. Emotional Intelligence is significantly and positively associated with the students' academic achievement. (Maizatul Akmal Mohd Mohzan et al 2013, Oyesojl A. Aremu et al 2006).Emotional intelligence has positive impact on students' academic achievement.( Baljinder Singh A/L Maghar Singh and Kuldip Singh2009) A study on emotional intelligence and academic performance in first and final year medical students indicated that students who were more emotionally intelligent performed better in their academics(Boon How Chew et al 2013) A study on relationship between psychosocial factors and emotional intelligence on school students, indicated that the female had higher academic achievement and emotional intelligence than male.( Bruni et al. (2006).

\section{Emotional Intelligence and Birth Order:}

Birth order is the sequence in which children are born into a family, such as first born, middle born and last born. Birth order plays a vital role in determining the emotions among siblings. Personality of child is significantly associated with birth order and it affects intelligence and growth of a child. The children who born first in their family remain supportive, cooperative and responsible. They take care of their young brothers and sisters while middle born children suffer in different complexes and inferior feelings. They feel competition with their first born. (Adler (1956).

The children who born first in their families have characteristics of responsibility, intellectually sound, obedient and least emotional, and later born have the characteristics of demonstrative more rational, aggrieved and chatty. They make clear, the first born are considered, more logical than later. Through their studies they claimed, oldest children achieve higher academic proficiencies, than later born. (Herrera and Zonjanc (2003)). Another study revealed that later born children remained the status conscious than first-born's and their first goal is to find a family position.( Sulloway (2007). Convergence theory concluded that birth order and emotional intelligence have impact on each other.( Zajonc (2001)There is no significant difference in EI of female students with respect to birth order. Based on the literature review the following hypotheses are formulated.

H1: Emotional intelligence has positive correlation with academic efficiency.

H2: Female students have higher level of emotional intelligence than male students. 


\section{A Study on Emotional Intelligence In Relation To Academic Efficiency, Gender and Birth Order among Technical Graduates: In Indian Context}

H3: First born students have higher level of emotional intelligence than later born students.

\section{RESEARCH METHODOLOGY}

\section{Research Design}

The quantitative design methodology employed in this study is correlation research. This design is selected because the study aims to examine the relationship between Emotional Intelligence and Academic Achievement among students. Therefore the independent variable examined in this study is students' level of Emotional Intelligence; where as the dependent variable is students’ Academic Efficiency level.

\section{Measurements}

Since the study is quantitative study, questionnaire method is used for data collection. The questionnaire used in this study consists of 2 Sections. Section A (Demographic profile ) requires participants to provide background information such as gender, birth order, geographic origin parental education and socio economic status, Section B, attempts to measure students' level of Emotional Intelligence and academic efficacy. Respondents were required to respond to the items which employed a 5-point Likert scale in which they have to rate their responses ranging from 1 which indicated Strongly Disagree to 5 which indicated Strongly Agree. There are 22 items in Section B. Out of which 16 items are used to measure the four domains of emotional intelligence (perception of emotions, managing own emotions ,managing other's emotions and understanding emotions). The reliability coefficient (alpha) of emotional intelligence scale is (0.82) and 6 items are used to measure the students' academic efficiency. The reliability coefficient (alpha) of academic efficiency is (0.73).

\section{Sample size}

Random sampling technique is used for the present study. Sample size is taken as 176 students (male students -112, female students-64) who are studying final year undergraduate engineering course in private engineering colleges located in Nellore district of Andhra Pradesh, India.

\section{RESULTS AND DISCUSSION}

Table.1 Correlation coefficient between EI and Academic Efficiency

\begin{tabular}{|c|c|c|c|c|}
\hline Variables & Cronbach alpha & Mean & S.D & R \\
\cline { 1 - 4 } Emotional Intelligence & 0.82 & 3.95 & 0.61 & \multirow{2}{*}{$0.45^{*}$} \\
\hline Academic efficiency & 0.73 & 3.85 & 0.79 & \\
\hline
\end{tabular}

$* \mathrm{P}<0.05$

Table.1 Shows a descriptive statistics of the variables and correlation coefficient between EI and Academic efficiency ( $\mathrm{N}=176)$.Descriptive statistics of the variables revealed that mean score for Emotional intelligence on a 5 point scale was 3.95(SD 0.61),Academic achievement was 


\section{A Study on Emotional Intelligence In Relation To Academic Efficiency, Gender and Birth Order among Technical Graduates: In Indian Context}

3.85(SD 0.79) correlation analysis revealed that emotional intelligence has significant positive correlation with academic efficiency $(\mathrm{r}=0.45, \mathrm{p}<0.05)$, which means that higher the level of emotional intelligence, better they perform academically. Thus the result supports the hypothesis (H1),'emotional intelligence has positive correlation with academic efficiency'. Researchers find Emotional Intelligence is significantly and positively associated with the students' academic achievement. (Maizatul Akmal Mohd Mohzan et al 2013, Oyesojl A. Aremu et al 2006, Shahzada et al 2011). A study on emotional intelligence and academic performance in first and final year medical students indicated that students who were more emotionally intelligent performed better in their academics (Faezah Hassan et al 2013).The result of the present study is also in consistent with the previous researchers result.

Table.2 Descriptive analysis of four domains of emotional intelligence

\begin{tabular}{|c|c|c|}
\hline Domain & Mean & SD \\
\hline Perception of emotions & 3.73 & 0.95 \\
\hline Managing own emotions & 3.81 & 0.92 \\
\hline Managing other's emotions & 3.85 & 0.86 \\
\hline Understanding of emotions & 4.13 & 0.75 \\
\hline
\end{tabular}

Table.3 Correlation between four domains of Emotional Intelligence and Academic Efficiency

\begin{tabular}{|c|c|c|}
\hline Domain & r & \multirow{2}{*}{ Significance } \\
\hline Perception of emotions & 0.168 & \\
\hline Managing own emotions & 0.364 & \multirow{2}{*}{$\mathrm{P}<0.05$} \\
\hline Managing other's emotions & 0.210 & \\
\hline Understanding of emotions & 0.268 & \\
\hline
\end{tabular}

Descriptive statistics of four domains of emotional intelligence revealed that respondents in the study have higher level of emotional intelligence for four domains investigated in the present study with $(\mathrm{M}=3.73, \mathrm{SD}=0.95)$ for perception of emotions, $(\mathrm{M}=3.81, \mathrm{SD}=0.92)$ for managing own emotions( $\mathrm{M}=3.85, \mathrm{SD}=0.86)$ for managing other's emotions( $\mathrm{M}=4.13, \mathrm{SD}=0.75)$ for understanding emotions. However, the determination of the correlation between the four domains of emotional intelligence and academic efficiency as presented in table 3 shows that all four domains of emotional intelligence significantly associated with academic efficiency. The findings of the present study indicates that students who are well in understanding and managing their own emotions and other's emotions can better cope effectively with the academic pressure for their academic excellence in education. Research indicates that emotional knowledge, skills, and intelligence do play a vital role in achieving higher academic efficiency and improving quality of education. (Low et al., (2004)).

(C) The International Journal of Indian Psychology, ISSN 2348-5396 (e)| ISSN: 2349-3429 (p) | 190 
A Study on Emotional Intelligence In Relation To Academic Efficiency, Gender and Birth Order among Technical Graduates: In Indian Context

Table.4 Mean differences in Emotional intelligence with respect to gender

\begin{tabular}{|c|c|c|c|c|c|}
\hline Gender & $\mathbf{N}$ & Mean & SD & SEM & \multirow{2}{*}{ MD } \\
\hline Male & 112 & 3.95 & 0.68 & 0.064 & \multirow{2}{*}{0.1} \\
\hline Female & 64 & 4.05 & 0.51 & 0.082 & \\
\hline
\end{tabular}

The result revealed that mean difference among male and female students on emotional intelligence score is significant. Female students have higher level of emotional intelligence than male students. Thus in the present study hypothesis (H2),'female students have higher level of EI than male students', is accepted. An empirical Study on PG students indicated that the level of emotional intelligence among female students was higher than it was in male students (Rajendra Prasad Das TapaS Lata Sahu2015). A study on higher secondary school student indicated that female students scored high emotional intelligence as compared to male students. (Muhammad Akbar et al 2011).The result of the present study is also in consistent with the result of previous research.

Table.5 Mean differences in Emotional intelligence with respect to birth order

\begin{tabular}{|c|c|c|c|c|c|}
\hline Birth order & N & Mean & SD & SEM & MD \\
\hline First born & 97 & 3.96 & 0.51 & 0.052 & \multirow{2}{*}{0.01} \\
\hline Later born & 79 & 3.95 & 0.72 & 0.081 & \\
\hline
\end{tabular}

The result revealed that mean difference of emotional intelligence scale of first born and later born is significant. First born students have higher level of emotional intelligence than later born students. Thus, the hypothesis (H3),'First born students have higher level of emotional intelligence than later born students', is accepted. The present study results are in the same line with previous researchers result (Sulloway (2007) Walton (2001)).

\section{CONCLUSIONS}

Many students graduate from engineering every year in India. Most of these graduates abandon their profession for which they were certified competent and skilled before graduation. They migrate to metropolitan cities in search of jobs that are difficult to secure. It was found that higher level of emotional intelligence and academic efficiency helps them to secure jobs. Since the respondents are future engineers it is necessary for them to possess emotional intelligence skills which will enable them to become good leaders and managers. Based on the result of the present study it is found that respondents studying final year engineering graduation have higher level of emotional intelligence and academic efficiency. From the result it is also found that there is a significant positive relationship between student's emotional intelligence and academic efficiency. Therefore, since the findings of the study suggests that respondents are future engineers with high level of emotional intelligence, it is expected of them to be able take on the challenge to achieve their future goals and to adapt to the demanding and stress full working environment. 


\section{A Study on Emotional Intelligence In Relation To Academic Efficiency, Gender and Birth Order among Technical Graduates: In Indian Context}

\section{Acknowledgments}

The author appreciates all those who participated in the study and helped to facilitate the research process.

Conflict of Interests: The author declared no conflict of interests.

\section{REFERENCES}

Allport, G. W. (1937). Personality: A psychological interpretation. New York: Holt.

Allport, G. W. (1963). Pattern and growth in personality. London, New York: Holt.

Costa, Jr., P. T. \& Mc Crae, R. R. (1992). NEO PI R Professional Manual, Florida: Psychological Assessment Resource Inc.

Diener, E. \& Diener, M. (1995). Cross cultural correlates of life satisfaction and self esteem. Journal of Personality and Social Psychology, 68, 653-663.

Diener, E., \& Seligman, M. E. P. (2002). Very happy people. Psychological Science, 13(1), 8184.

Diener, E., Oishi, S., \& Lucas, R. E. (2003). Personality, culture and subjective wellbeing: Emotional and cognitive evaluations of life. Annual Review of Psychology, 54, 403-425.

Diener, E., Suh, E. M., Lucas, R. E., \& Smith, H. L. (1999). Subjective wellbeing: Three decades of progress.

Dohrenwend, B. S. \& Dohrenwend, B. P. (Eds.) (1979). Stressful life events: Their nature and effects. New York: Wiley.

Erikson, E. (1968). Identity: Youth \& Crisis, New York: Norton.

Eysenck, H. J. (1952). Scientific Study of Personality. New York: Mac Millan.

Guilford, J. P. (1959). Personality. New York: Mc Graw Hill \& Company.

Gutierrez, J. L. G., Jimenez B. M., Hernandez, E. G., \& Puente, C. P. (2005). Personality and subjective wellbeing: Big five correlates and demographic variables. Personality and Individual Differences, 38(7), 1561-1569.

Halama, P. (2005). Relationship between meaning in life and the big five personality traits in young adults and the elderly. Studia Psychologica, 47(3), 167-178.

Headey, B. and Wearing, A. (1992). Understanding Happiness: A theory of subjective wellbeing. Melbourne, Australia: Longman Cheshire.

Hussain, S. \& Kumari, M. (1995). Eysenck’s Personality Dimensions in Relation to Ego Strength and Adjustment. Journal of Personality and Clinical Studies, 11(1-2), 43-48.

Keyes, C. L. M. (1998). Social Wellbeing. Social Psychology Quarterly, 61(2), 121-140.

Keyes, C. L. M., Schmotkin, D. \& Ryff, C. D. (2002). Optimizing Wellbeing: The empirical encounter of two traditions. Journal of Personality and Social Psychology, 82(6), 10071022. 


\section{A Study on Emotional Intelligence In Relation To Academic Efficiency, Gender and Birth Order among Technical Graduates: In Indian Context}

Keyes, C. L. M., Schmotkin, D. \& Ryff, C. D. (2002). Optimizing Wellbeing: The empirical encounter of two traditions. Journal of Personality and Social Psychology, 82(6), 10071022.

Levi, L. (1987). Filling work to human capacities \& needs improvements in the contents and organization of work. In Kaline et al., Psychological Factors at work.

Libran, E. C. \& Howard, V. N. (2006). Personality Dimensions and subjective wellbeing. Spanish Journal of Psychology, 9(1), 38 - 44.

Lynn, M. \& Steel, P. (2006). National Differences in subjective wellbeing: The interactive effects of extraversion and neuroticism. Journal of Happiness Studies, 7(2), 155-165.

Mc Clelland, D. C. (1951). Personality. New York: William Son Associates.

McCrae, R. R \& John, O. (1992). An introduction to the five-factor model and its applications. Journal of Personality, 60(2), 174-214.

Pollard, E. L., \& Lee, P. D. (2003). Child Wellbeing: A Systematic Review of the Literature. Social Indicators Research, 61(1), 59-78.

Psychological Bulletin, 125, 276-302.

Reifler, C. B., \& Liptzin, M. B. (1969). Epidemiological studies of college mental health. Archives of General Psychiatry, 20, 327 - 333.

Ruiz, V. M. (2005). The Five Factor Model of Personality, Subjective Wellbeing, and Social Adaptation: Generalizability to the Spanish context. Psychological Reports, 96(2), 863866.

Ruiz, V. M. (2005). The Five Factor Model of Personality, Subjective Wellbeing, and Social Adaptation: Generalizability to the Spanish context. Psychological Reports, 96(2), 863866.

Ryff, C. D. (1995). Psychological wellbeing in adult life. Journal of Personality and Social Psychology, 52, 1069-1081.

Ryff, C. D., (1989a). 'Happiness is everything, or is it? Explorations on the meaning of psychological wellbeing.' Journal of Personality and Social Psychology, 57(6), pp.10691081.

Ryff, C. D., (1989b). 'Beyond Ponce de Leon and life satisfaction: New directions in quest of successful aging.' International Journal of Behavioural Development, 12, 35-55.

Ryff, C. D., (1989b). 'Beyond Ponce de Leon and life satisfaction: New directions in quest of successful aging.' International Journal of Behavioural Development, 12, 35-55.

Singh. A. P. (2009). Personality Traits and Leadership Effectiveness: An Exploratory Study. Indian Journal Halama, P. (2005). Relationship between meaning in life and the big five personality traits in young adults and the elderly. Studia Psychologica, 47(3), 167-178.

How to cite this article: Vasavi B, Katyayani J, Sudhir B (2017), A Study on Emotional Intelligence In Relation To Academic Efficiency, Gender and Birth Order among Technical Graduates: In Indian Context, International Journal of Indian Psychology, Volume 4, Issue 2, No. 88, ISSN:2348-5396 (e), ISSN:2349-3429 (p), DIP:18.01.080/20170402, ISBN:978-1-36574161-6 